\title{
CONTAMINATION OF PUBLIC PARKS AND SQUARES FROM GUARULHOS (SÃO PAULO STATE, BRAZIL) BY Toxocara spp. AND Ancylostoma spp.
}

\author{
Jacó Pereira MARQUES, Catarina de Rezende GUIMARÃES, Ailton VILAS BOAS, Paulo Usignolo CARNAÚBA \& Josué de MORAES
}

\begin{abstract}
SUMMARY
The contaminated soil with mammal feces is an important factor of risk to infection with zoonotic diseases. Amongst these zoonoses are visceral larva migrans and cutaneous larva migrans caused by Toxocara spp. and Ancylostoma spp., respectively. The aim of this study was to assess the environmental contamination by Toxocara spp. eggs and hookworms (Ancylostoma spp.) in public parks and squares in the city of Guarulhos, a metropolitan area of São Paulo, São Paulo State, Brazil. Soil samples were collected, between September and December 2010, and examined using the centrifugal flotation technique with sodium dichromate and zinc sulphate as well as the modified Baermann method. Notably, 35 (74.5\%) of the 47 districts surveyed in Guarulhos possessed samples contaminated with Toxocara spp. and/or eggs or larvae of Ancylostoma spp. The frequency of Toxocara spp. and Ancylostoma spp. in the samples from public areas was $68.1 \%$ and $46.8 \%$, respectively. Overall, the eastern side of Guarulhos is the region with the highest occurrence of causative agents of larva migrans. In all collection sites, the presence of feces from dogs and cats accompanied by their owners and stray animals were observed. Notably, it is important to adopt measures to control dog and cat breeding, to treat infected animals, and provide health education to the population.
\end{abstract}

KEYWORDS: Larva migrans; Toxocara spp.; Ancylostoma spp.; Soil contamination; Guarulhos.

\section{INTRODUCTION}

The presence of mammal feces in the soil of urban areas is an important public health problem in several countries, mainly due to the presence of parasites that can cause larva migrans syndrome in humans. There are traditionally acknowledged zoonotic diseases, such as visceral larva migrans caused by Toxocara spp. and cutaneous larva migrans caused by Ancylostoma spp. These parasitic zoonoses are associated with the presence of animals, mainly dogs and cats in places where humans can become infected, such as squares and public parks ${ }^{12,17,18,37}$.

The growing number of domestic animals, especially in large urban centers, has increased the contact between animals and humans and heightened exposure risk to parasites responsible for zoonosis. The invasion of the human body by nematode parasites of other animals is an atypical development of the parasitic species involved, which are unable to complete its life cycle. Under these conditions, it is observed that the infective larval form cannot progress to the adult worm, and its abnormal migration in the host stops in different tissues such as skin, eye, liver, lungs or other organs ${ }^{12,17,18}$. Nematodes that penetrate through the skin but still wander between the epidermis and dermis, resulting in clinical cutaneous larva migrans ${ }^{12,18}$, whereas nematodes that enter the body orally and should experience the typical pulmonary cycle after reaching the digestive tract are likely to finally reside in the liver or lungs or other organs, causing the clinical syndrome visceral larva migrans ${ }^{17}$.

The parasites causing larva migrans syndrome persist everywhere there are dogs and cats infected with nematodes, especially Ancylostoma spp. and Toxocara spp. Given the ubiquity of dogs and cats, which is exacerbated in cities by human population density, pets and stray animals, the control of parasitism is very difficult ${ }^{17,26,37}$. In fact, in many cities, large population of animals can circulate freely through the streets and public squares that may be taken by the owners. In these places, the animals defecate, contaminating the environment with eggs or larvae of parasites, which favors zoonotic transmission.

Larva migrans syndromes, especially toxocariasis and hookworm infections, are amongst the most prevalent worldwide, including industrialized countries, but these diseases remain unknown by the population ${ }^{18,44}$. Environmental contamination with helminth eggs is common in urban public places in most countries. For example, the percentage of soil contaminated by Toxocara spp. eggs has ranged between $12 \%$ and $60.3 \%$ in Brazil $^{4,21,37,43}, 14.4 \%$ and $20.6 \%$ in the United States of America, $13.0 \%$ and $87.1 \%$ in Europe, $6.6 \%$ and $63.3 \%$ in Asia and $30.3 \%$ and $54.5 \%$ in Africa $^{37}$. 
MARQUES, J.P.; GUIMARÃES, C.R.; VILAS BOAS, A.; CARNAÚBA, P.U. \& MORAES, J. - Contamination of public parks and squares from Guarulhos (São Paulo State, Brazil) by Toxocara spp. and Ancylostoma spp. Rev. Inst. Med. Trop. Sao Paulo, 54(5): 267-71, 2012

Despite the high incidence of larva migrans syndromes in various regions, few studies have assessed soil contamination in large urban centers $^{3,10,14,15,18,37,39}$. For example, in Guarulhos, a metropolitan area of São Paulo (São Paulo State, Brazil), there is little analysis of soil contamination by helminths that cause zoonoses. Thus, the objective of this study was to analyze soil samples collected from public parks and squares of the city of Guarulhos. Guarulhos is the second largest city in São Paulo, with a population of approximately 1.3 million people distributed in its 47 districts. Currently, Guarulhos is the $8^{\text {th }}$ richest city in Brazil with a production that represents more than $1 \%$ of Gross Domestic Product (GDP) $)^{32}$. Over the last decades, several population groups have moved to Guarulhos in search of employment opportunities and housing. Influx of new residents led to erratic construction of an environment marked by strong demand, particularly in the health sector. The diversity of squares and parks provide leisure options for the population.

\section{MATERIAL AND METHODS}

Guarulhos is one of 39 municipalities that is in the metropolitan area of São Paulo (São Paulo State, Brazil) and is located $17 \mathrm{~km}$ from the capital in the northeast. The city is strategically located between two major national highways, Presidente Dutra Highway and Fernão Dias, the main axis of development of the country (São Paulo/Rio de Janeiro and São Paulo/Minas Gerais). Guarulhos has favorable environmental conditions, such as humid subtropical climate, mean annual temperature of $19^{\circ} \mathrm{C}$, relative humidity average of $81.1 \%$ and average annual rainfall of $1470 \mathrm{~mm}$ to support the physical expansion of parasitic diseases ${ }^{27,32}$.

From September to December 2010, soil samples from 120 public parks and squares distributed within 47 districts of Guarulhos were examined. Each sample consisted of approximately 250 grams of soil collected by scraping with a metal spoon the soil surface to a 5 to 10 $\mathrm{cm}$ depth at five different points per site ${ }^{5,8,24}$. After mixing the five collected samples, the pooled samples analyzed on the same day as collected by the centrifugal flotation technique with sodium dichromate $(d=1.35)$ and zinc sulphate $(d=1.20)$ and the modified Baermann method $^{9,38}$. The identification of larvae and eggs of parasites causing larva migrans, Toxocara spp. and Ancylostoma spp., was performed based on morphology using a light microscope.

\section{RESULTS}

Notably, $35(74.5 \%)$ of the 47 districts surveyed in Guarulhos possessed samples contaminated with Toxocara spp. and/or eggs or larvae of Ancylostoma spp. (Fig. 1).

The frequency of Toxocara spp. and Ancylostoma spp. in soil samples from public parks and squares in Guarulhos was $68.1 \%$ and $46.8 \%$, respectively, whereas concomitant occurrence of these two nematodes was recorded in 19 districts. Moreover, in general, districts in the eastern part of the city were those with the highest prevalence of Toxocara spp. and Ancylostoma spp., whereas the contamination was lower in the central region (Fig. 1). Overall, regarding the Toxocara eggs in soil samples, the light microscopic investigations showed the presence of undeveloped and embryonated eggs.

In the public areas of all districts, the presence of stray dogs and cats and often-domiciled animals, which were accompanied by their owners,

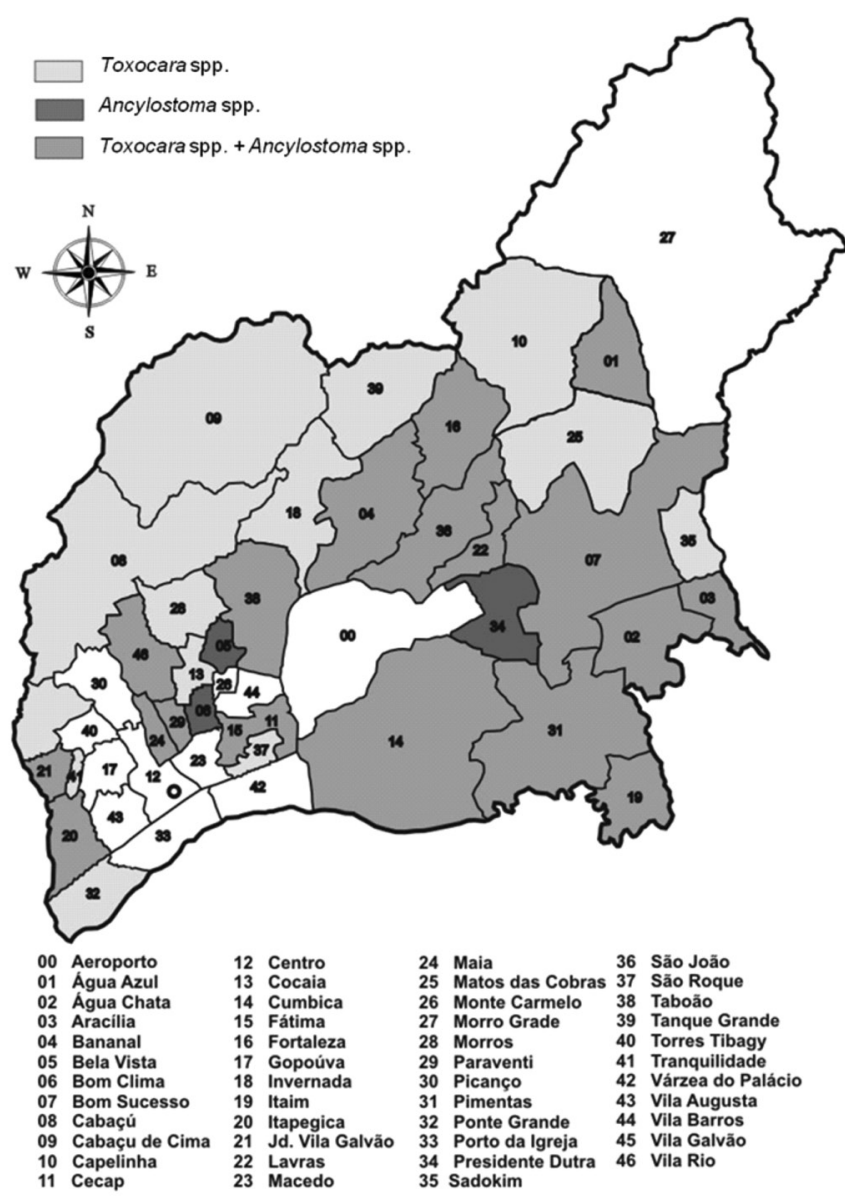

Fig. 1 - Contaminated regions of Guarulhos, São Paulo, Brazil with egg and/or larvae of Toxocara spp. and Ancylostoma spp. (September to December, 2010).

was noted. Additionally, we detected the presence of dog and cat feces scattered across several streets, squares and parks of the city.

\section{DISCUSSION}

The soils of squares and public parks are the main transmission route of parasitic zoonoses to the human population. Amongst these zoonoses are visceral larva migrans and cutaneous larva migrans caused by Toxocara spp. and Ancylostoma spp., respectively ${ }^{2,12,17,18}$. Studies on the prevalence of parasites causing larva migrans have been conducted in various regions of the world, especially by either stool examinations of dogs and cats, or soil contamination assessments for helminth eggs and larvae $e^{2,4,20,26}$. In general, many authors have sought to assess the degree of soil contamination in public places by measuring Toxocara spp. levels and are less interested in environmental contamination by eggs or larvae of Ancylostoma spp. ${ }^{11}$. This is mainly because human toxocariasis ranks among the most common zoonotic infections worldwide, even found in industrialized and developing countries, with an important clinical expression $^{18,37}$.

Eggs and larvae of Toxocara spp. and Ancylostoma spp. have been found in soil samples worldwide. They are present in public and private 


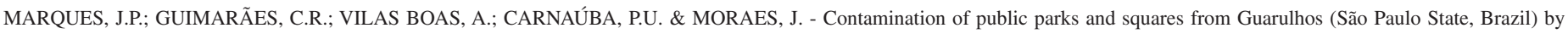
Toxocara spp. and Ancylostoma spp. Rev. Inst. Med. Trop. Sao Paulo, 54(5): 267-71, 2012.

places such as playgrounds, parks, sandpits, pavements, streets, gardens and fields. In the present study there was a high frequency $(74.5 \%)$ of Ancylostoma spp. and Toxocara spp. in the 47 districts in Guarulhos. This high rate is further justified by the recovery of Toxocara spp. eggs $(68.1 \%)$ than hookworms $(46.8 \%)$. This percentage rate is markedly higher than the figures published by other researchers in different regions of the world $110,13,14,15,22,24,25$. For example, the frequency of Toxocara ssp. observed in Guarulhos was higher than that found in Bolivar, Venezuela $(55 \%)^{13}$, Kaduna, Nigeria $(50.4 \%)^{22}$, Prague, Czech Republic $(20.4 \%)^{14}$, Sapporo, Japan $(7.47 \%)^{25}$ and London, United Kingdom $(6.3 \%)^{15}$ as well as in different regions of Poland $(2-37 \%)^{26}$ and Spain $(3.8-52 \%)^{10,24}$. However, the level of soil contamination in Guarulhos was similar to the $67 \%$ recorded in Murcia (Spain) by RUIZ DE YBÁÑEZ et al. $(2001)^{39}$ and the $62.5 \%$ in Kirikkale (Turkey) by AYDENIZÖZ OZKAYHAN (2006) ${ }^{1}$. Concerning the Brazilian cities, in general, the degree of contaminated places in the present study by Toxocara spp. is higher than many cities, where studies found that soil contamination by Toxocara spp. varied from 12 to $60.3 \%$ 4,21,37,43. Indeed, for example, in Moreno (Pernambuco State), LIMA et al. $(2005)^{21}$ found contamination with Toxocara spp. eggs in $12 \%$ of the soil samples, whereas TIYO et al. $(2008)^{43}$ reported the occurrence of Toxocara spp. eggs in $60.3 \%$ of the soil samples from public lawns of the town of Maringá, Paraná State. Furthermore, in the State of São Paulo, the frequency of Toxocara spp. observed in Guarulhos was higher than that found in Sorocaba $(53.5 \%)^{7}$, Fernandópolis $(20.89 \%)^{5}$, Ribeirão Preto $(20.5 \%)^{3}$ and Botucatu $(17.5 \%)^{40}$.

With regards to soil samples with eggs and larvae of Ancylostoma spp., the frequency in this study (46.8\%) was higher than the cities of some countries, such as Bogotá, Colombia $(10.7 \%)^{31}$, Kaduna, Nigeria $(9 \%)^{22}$, Wrocław, Poland $(4.9 \%)^{30}$, Madrid, Spain $(3 \%)^{10}$ and different regions of Costa Rica $(2 \%)^{29}$. Concerning the Brazilian cities, our results with hookworms in Guarulhos were similar to the recorded in Araçatuba (São Paulo State) by NUNES et al. $(2000)^{28}$, who found $46 \%$ of the sand samples contaminated with Ancylostoma spp. larvae. On the other hand, the degree of contamination by hookworm was higher than recovered in some cities, such as Fernandópolis, São Paulo $(1.8 \%)^{5}$, Santos, São Paulo $(15 \%)^{35}$, Duque de Caxias, Rio de Janeiro $(33.5 \%)^{42}$ and Araçatuba, São Paulo $(37.5 \%)^{28}$. In contrast, contamination rates higher than our results were noted in Santa Maria (Rio Grande do Sul State) by CORRÊA \& MOREIRA $(1996)^{8}$, who found $93.3 \%$ of the public squares' land contaminated with eggs of Ancylostoma spp. In addition, GUIMARÃES et al. $(2005)^{16}$ reported the occurrence of eggs and larvae of hookworms in $69.6 \%$ of the soil samples from public squares of the town of Lavras (Minas Gerais State).

As shown in Figure 1, the central region of Guarulhos had the lowest rate of contamination by nematode Toxocara spp. and Ancylostoma spp. In other areas, soil contamination was higher with Toxocara spp. These data agree with the observations of CAPUANO \& ROCHA $(2005)^{3}$ who examined soil samples from public squares in Ribeirão Preto (São Paulo State) and found environmental contamination by Toxocara spp., whose frequency was lower in the central region. Moreover, the results of this study also agree with CORRÊA \& MOREIRA $(1996)^{8}$; in this case, the authors showed that in Santa Maria (Rio Grande do Sul State), the prevalence of Ancylostoma spp. was lower in the soil of the central public squares. The difference in the centre compared with other regions is most likely due to a more targeted public intervention to those regions, such as cleaning, maintenance, presence of refuse dumps and controlled access by the use of fences, while those regions still contained a high level of soil contamination. In fact, in public spaces where animals are allowed access, they can liberate eggs and or larvae of parasites into the environment through their feces and thus generate a risk for the population ${ }^{36,41}$. The high prevalence in other areas indicates that socioeconomic indicators, such as low income and education level, are related to the spread of parasites with zoonotic potential in the environment ${ }^{17,41}$. Additionally, the canine population density varies from region to region, especially stray dogs. This one factor is related to socio-economic aspects of each population group in the same city ${ }^{41,42}$; in this context, the peripheral areas of large cities offer better conditions for the high prevalence of helminth parasites $1,10,13,14,15,22,24,25$. The study results obtained in Guarulhos, where approximately $75 \%$ of districts had contaminated the soil with parasites responsible for zoonoses, indicate that the majority of the municipal population is at zoonotic risk.

Human nematode diseases are more prevalent in tropical settings than in temperate regions, and are more prevalent in rural populations than in urban populations in the same region ${ }^{37}$. Egg resistance, to both chemical and climatic factors, influences their viability in the environment over long periods of time ${ }^{41}$. Type of soil, ambient temperature and humidity are the main factors that determine the time it takes to evolve from egg to larvae ${ }^{26}$. In Guarulhos, between September and December 2010, the spring season, the average temperature was $22.5^{\circ} \mathrm{C}\left(16.4-25.8^{\circ} \mathrm{C}\right)^{6}$ and thus it has the correct temperature to favor maintenance and development to nematode eggs or larvae.

Analyses of fecal samples found in public places can predict levels of soil contamination. However, comparison between different reports should consider several methodological biases. MIZGAJSKA $(2001)^{26}$ related that during the course of sampling and laboratory analyses many factors influence the results of soil examinations and these include: sample site selection, number and volume of samples, depth of sampling, season of examination, method of egg recovery, type of soil examined, preservation of samples and laboratory skills. In this context, many techniques have been described, and they vary in the percentage of parasites recovered ${ }^{23}$. In this study, soil samples were analyzed using the flotation technique according to DADA $(1979)^{9}$ with sodium dichromate $(d=1.35)$ and zinc sulphate $(d=1.20)$ for helminth eggs and the modified Baermann method for larvae recovered according to RUGAI et al. $(1954)^{38}$. Although the methods used to recover zoonotic parasites in soil are not standardized and are not always comparable ${ }^{23,26}$, the techniques used in our study are in agreement with others studies and they are considered effective $\mathrm{e}^{16,21,23,28}$. Another important aspect in parasite detection is the type of soil ${ }^{21,22,23,26,41}$. In this study, we observed that soil from all studied place and squares were primarily composed of sand, and more rarely clay soil. It has been described that sandy soils represent an important source of human infection by parasites ${ }^{35}$.

Approximately one decade ago, RAGOZO et al. (2002) ${ }^{33}$ analyzed stool samples from 31 cats that were captured in the streets of Guarulhos, and amongst helminths, Toxocara cati and Ancylostoma spp. were the most prevalent. Additionally, the authors have emphasized the importance of stray cats in the epidemiology of zoonoses in the city. In our study, it was noted that many animals (resident, domiciled or semi-errant) defecated in the soil of most parks and public squares of Guarulhos. These dogs and cats are on public roads and thus represent an important aspect in the transmission of zoonoses in urban areas. Moreover, from 
MARQUES, J.P.; GUIMARÃES, C.R.; VILAS BOAS, A.; CARNAÚBA, P.U. \& MORAES, J. - Contamination of public parks and squares from Guarulhos (São Paulo State, Brazil) by Toxocara spp. and Ancylostoma spp. Rev. Inst. Med. Trop. Sao Paulo, 54(5): 267-71, 2012.

an epidemiological point of view, the World Health Organization (WHO) recommends that the dog population in each location should not exceed $10 \%$ of the human population ${ }^{45}$. In Guarulhos, the estimate is seven dogs per person ${ }^{19}$, which corresponds to approximately $15 \%$ of the human population. Thus, considering that Guarulhos is one of the most populous cities in Brazil, with approximately 1.3 million inhabitants, it is estimated that the dog population is almost 200,000 .

Finally, larva migrans syndrome represents a global public health problem and remains neglected in many countries ${ }^{17,18,20,37,44,45}$. The intervention of the public service to preserve the population's health and animal welfare is a great challenge ${ }^{12,18,34,44}$. Considering the high incidence of parasites with zoonotic potential in the soil of the public areas of Guarulhos, it is necessary to highlight the importance of adopting educational and dog and cat breeding control measures to reduce the risk of exposure to these parasites that cause zoonoses in adults and especially children.

\section{CONFLICT OF INTEREST}

The authors have declared that no competing interests exist.

\section{RESUMO}

\section{Contaminação de parques e praças públicas por Toxocara spp. e Ancylostoma spp., no município de Guarulhos, São Paulo, Brasil}

A contaminação do solo com fezes de animais mamíferos representa importante fator de risco para a ocorrência de zoonoses, sobretudo a larva migrans visceral e a larva migrans cutânea, causadas por Toxocara spp. e Ancylostoma spp., respectivamente. O presente estudo teve como objetivo verificar a contaminação ambiental por Toxocara spp. e Ancylostoma spp. em amostras de solos coletadas de praças e parques públicos do município de Guarulhos, região metropolitana de São Paulo (São Paulo, Brasil). No período de setembro a dezembro de 2010 as amostras do solo foram coletadas e examinadas pela técnica de centrífugo-flutuação, com dicromato de sódio e sulfato de zinco, e pelo método de Baermann modificado. Dos 47 distritos analisados, 35 (74,5\%) estavam contaminadas com ovos de Toxocara spp. e/ou ovos ou larvas de Ancylostoma spp., sendo que a frequencia de Toxocara spp. e Ancylostoma spp. foi de $68,1 \%$ e $46,8 \%$, respectivamente. No geral, a Zona Leste de Guarulhos foi a região com maior ocorrência desses parasitas com potencial zoonótico. Em todas as áreas públicas, dos 47 distritos, notou-se a presença de fezes de cães e gatos, assim como animais errantes ou acompanhados de seus proprietários. Faz-se necessário salientar a importância da adoção de medidas de controle reprodutivo de cães e gatos, o tratamento dos animais infectados, assim como medidas educativas para reduzir os riscos de crianças e adultos à exposição desses parasitas causadores de zoonoses.

\section{ACKNOWLEDGMENTS}

The authors would like to thank Jairo de Moraes and Aline A. L. Carvalho for their contribution to the physical and geographical aspects of Guarulhos and Etielle B. Andrade for her artwork. We are indebted to Fabiana Barros, Andréia Assumpção, Sandra E. Oshiro, Roseli S. Lima and many colleagues from Faculdades Integradas Torricelli (Guarulhos, São Paulo) for their help in sample collection from the very beginning of this project. The authors are also grateful to Dr. Kendi Okuda (Department of Medicine, University of Massachusetts Medical School, USA) for criticism and revision of the manuscript. This work received financial support from Clínica Veterinária Fullpet (Guarulhos, São Paulo).

\section{AUTHORS CONTRIBUTIONS}

Conceived and designed the experiments: JP Marques, J Moraes. Performed the experiments: JP Marques, CR Guimarães, A Vilas Boas. Analyzed the data: JP Marques, J Moraes. Contributed reagents/materials/ analysis tools: PU Carnaúba, JP Marques, CR Guimarães, A Vilas Boas, J Moraes. Wrote the paper: J Moraes.

\section{REFERENCES}

1. Aydenizöz Ozkayhan M. Soil contamination with ascarid eggs in playgrounds in Kirikkale, Turkey. J Helminthol. 2006;80:15-8.

2. Bowman DD, Montgomery SP, Zajac AM, Eberhard ML, Kazacos KR. Hookworms of dogs and cats as agents of cutaneous larva migrans. Trends Parasitol. 2010;26:162-7.

3. Capuano DM, Rocha G de M. Environmental contamination by Toxocara sp. eggs in Ribeirão Preto, São Paulo State, Brazil. Rev Inst Med Trop Sao Paulo. 2005;47:223-6.

4. Carvalho EA, Rocha RL. Toxocaríase: larva migrans visceral em crianças e adolescentes. J Pediatr (Rio J). 2011;87:100-10.

5. Cassenote AJ, Pinto Neto JM, Lima-Catelani AR, Ferreira AW. Contaminação do solo por ovos de geo-helmintos com potencial zoonótico na municipalidade de Fernandópolis, Estado de São Paulo, entre 2007 e 2008. Rev Soc Bras Med Trop. 2011:44:371-4.

6. Centro integrado de informações agrometeorológicas. Monitoramento agrometeorológico e climático. São Paulo, SP; 2011.

7. Coelho LM, Dini CY, Milman MH, Oliveira SM. Toxocara spp. eggs in public squares of Sorocaba, São Paulo State, Brazil. Rev Inst Med Trop Sao Paulo. 2001;43:189-91.

8. Corrêa GLB, Moreira WS. Contaminação do solo por ovos de Ancylostoma spp. em praças públicas, na cidade de Santa Maria, RS, Brasil. Rev FZVA. 1996;3:15-7.

9. Dada BJ. A new technique for the recovery of Toxocara eggs from soil. J Helminthol. 1979;53:141-4.

10. Dado D, Izquierdo F, Vera O, Montoya A, Mateo M, Fenoy S, et al. Detection of zoonotic intestinal parasites in public parks of Spain. Potential epidemiological role of microsporidia. Zoonoses Public Health. 2012;59:23-8.

11. de Castro JM, dos Santos SV, Monteiro NA. Contaminação de canteiros da orla marítima do Município de Praia Grande, São Paulo, por ovos de Ancylostoma e Toxocara em fezes de cães. Rev Soc Bras Med Trop. 2005;38:199-201.

12. Despommier D. Toxocariasis: clinical aspects, epidemiology, medical ecology, and molecular aspects. Clin Microbiol Rev. 2003;16:265-72.

13. Devera R, Blanco Y, Hernández H, Simoes D. Toxocara spp. and other helminths in squares and parks of Ciudad Bolívar, Bolivar State (Venezuela). Enferm Infecc Microbiol Clin. 2008;26:23-6.

14. Dubná S, Langrová I, Jankovská I, Vadlejch J, Pekár S, Nápravník J, et al. Contamination of soil with Toxocara eggs in urban (Prague) and rural areas in the Czech Republic. Vet Parasitol. 2007;144:81-6.

15. Gillespie SH, Pereira M, Ramsay A. The prevalence of Toxocara canis ova in soil samples from parks and gardens in the London area. Public Health. 1991;105:335-9. 
MARQUES, J.P.; GUIMARÃES, C.R.; VILAS BOAS, A.; CARNAÚBA, P.U. \& MORAES, J. - Contamination of public parks and squares from Guarulhos (São Paulo State, Brazil) by Toxocara spp. and Ancylostoma spp. Rev. Inst. Med. Trop. Sao Paulo, 54(5): 267-71, 2012.

16. Guimarães AM, Alves EG, de Rezende GF, Rodrigues MC. Ovos de Toxocara sp. e larvas de Ancylostoma sp. em praça pública de Lavras, MG. Rev Saúde Pública. 2005;39:293-5.

17. Heukelbach J, Feldmeier H. Epidemiological and clinical characteristics of hookworm-related cutaneous larva migrans. Lancet Infect Dis. 2008;8:302-9.

18. Hotez PJ, Wilkins PP. Toxocariasis: America's most common neglected infection of poverty and a helminthiasis of global importance? PLoS Negl Trop Dis. 2009;3:e400.

19. Instituto Pasteur de São Paulo. Informações e publicações. São Paulo, SP; 2006

20. Lee AC, Schantz PM, Kazacos KR, Montgomery SP, Bowman DD. Epidemiologic and zoonotic aspects of ascarid infections in dogs and cats. Trends Parasitol. 2010;26:15561.

21. Lima JL, Andrade LD, Santos AMA, Alves LC, Medeiros Z. Contaminação por ovos de Toxocara sp. em solo no município de Moreno, Estado de Pernambuco, Brasil. Braz J Vet Res Anim Sci. 2005;42:339-346.

22. Maikai BV, Umoh JU, Ajanusi OJ, Ajogi I. Public health implications of soil contaminated with helminth eggs in the metropolis of Kaduna, Nigeria. J Helminthol. 2008;82:113-8.

23. Mandarino-Pereira A, de Souza FS, Lopes CW, Pereira MJ. Prevalence of parasites in soil and dog feces according to diagnostic tests. Vet Parasitol. 2010;170:176-81.

24. Martínez-Moreno FJ, Hernández S, López-Cobos E, Becerra C, Acosta I, MartínezMoreno A. Estimation of canine intestinal parasites in Córdoba (Spain) and their risk to public health. Vet Parasitol. 2007;143:7-13.

25. Matsuo J, Nakashio S. Prevalence of fecal contamination in sandpits in public parks in Sapporo City, Japan. Vet Parasitol. 2005;128:115-9.

26. Mizgajska H. Eggs of Toxocara spp. in the environment and their public health implications. J Helminthol. 2001;75:147-51.

27. Moraes J, Silva MP, Ohlweiler FP, Kawano T. Schistosoma mansoni and other larval trematodes in Biomphalaria tenagophila (Planorbidae) from Guarulhos, São Paulo State, Brazil. Rev Inst Med Trop Sao Paulo 2009;51:77-82.

28. Nunes CM, Pena FC, Negrelli GB, Anjo CG, Nakano MM, Stobbe NS. Ocorrência de larva migrans na areia de áreas de lazer das escolas municipais de ensino infantil, Araçatuba, SP, Brasil. Rev Saúde Pública. 2000;34:656-8.

29. Paquet-Durand I, Hernández J, Dolz G, Zuñiga JJ, Schnieder T, Epe C. Prevalence of Toxocara spp., Toxascaris leonina and ancylostomidae in public parks and beaches in different climate zones of Costa Rica. Acta Trop. 2007;104:30-7.

30. Perec-Matysiak A, Hildebrand J, Zaleśny G, Okulewicz A, Fatuła A. The evaluation of soil contamination with geohelminth eggs in the area of Wrocław, Poland. Wiad Parazytol. 2008; 54:319-23

31. Polo-Terán LJ, Cortés-Vecino JA, Villamil-Jiménez LC, Prieto E. Contaminación de los parques públicos de la localidad de Suba, Bogotá con nemátodos zoonóticos. Rev Salud Publica (Bogota). 2007;9:550-7
32. Prefeitura Municipal de Guarulhos. Estatísticas e geografia. Guarulhos, SP; 2011.

33. Ragozo AMA, Muradian V, Ramos e Silva JC, Caravieri R, Amajoner VR, Magnabosco C, et al. Ocorrência de parasitos gastrintestinais em fezes de gatos das cidades de São Paulo e Guarulhos. Braz J Vet Res Anim Sci. 2002;39:244-6.

34. Reichmann MLAB, Figueiredo ACC, Pinto HBF, Nunes VFP. Controle de populações de animais de estimação. São Paulo: Instituto Pasteur; 2000. (Manuais, 6).

35. Rocha S, Pinto RM, Floriano AP, Teixeira LH, Bassili B, Martinez A, et al. Environmental analyses of the parasitic profile found in the sandy soil from the Santos municipality beaches, SP, Brazil. Rev Inst Med Trop Sao Paulo. 2011;53:277-81.

36. Rubel D, Wisnivesky C. Magnitude and distribution of canine fecal contamination and helminth eggs in two areas of different urban structure, Greater Buenos Aires, Argentina. Vet Parasitol. 2005;133:339-47.

37. Rubinsky-Elefant G, Hirata CE, Yamamoto JH, Ferreira MU. Human toxocariasis: diagnosis, worldwide seroprevalences and clinical expression of the systemic and ocular forms. Ann Trop Med Parasitol. 2010;104:3-23.

38. Rugai E, Mattos T, Brisola A. Nova técnica para isolar larvas de nematóides das fezes - modificação do método de Baermann. Rev Inst Adolfo Lutz. 1954;14:5-8.

39. Ruiz de Ybáñez MR, Garijo MM, Alonso FD. Prevalence and viability of eggs of Toxocara spp. and Toxascaris leonina in public parks in eastern Spain. J Helminthol. 2001;75:169-73

40. Santarém VA, Sartor IF, Bergamo FM. Contaminação, por ovos de Toxocara spp., de parques e praças públicas de Botucatu, São Paulo, Brasil. Rev Soc Bras Med Trop. 1998;31:529-32

41. Sommerfelt IE, Cardillo N, López C, Ribicich M, Gallo C, Franco A. Prevalence of Toxocara cati and other parasites in cats' faeces collected from the open spaces of public institutions: Buenos Aires, Argentina. Vet Parasitol. 2006;140:296-301.

42. Thomé SM, Lafayette EP, Pessoa Neto GR. Contaminação ambiental por ovos de Toxocara spp. e Ancylostoma spp. em praças públicas da cidade de Duque de Caxias, estado do Rio de Janeiro. Saude \& Amb Rev. 2008;3:30-32.

43. Tiyo R, Guedes TA, Falavigna DL, Falavigna-Guilherme AL. Seasonal contamination of public squares and lawns by parasites with zoonotic potential in southern Brazil. J Helminthol. 2008;82:1-6.

44. Wells DL. Public understanding of toxocariasis. Public Health. 2007;121:187-8

45. World Health Organization. Guidelines for dog population management. Geneve: WHO; 1990 .

Received: 14 March 2012

Accepted: 10 May 2012 


\section{Revista do Instituto de Medicina Tropical de São Paulo on line.}

Publications from 1987 to the present data are now available on:

http://www.scielo.br/rimtsp

PAST ISSUES 1959-1989 (PDF)

www.imt.usp.br/portal/

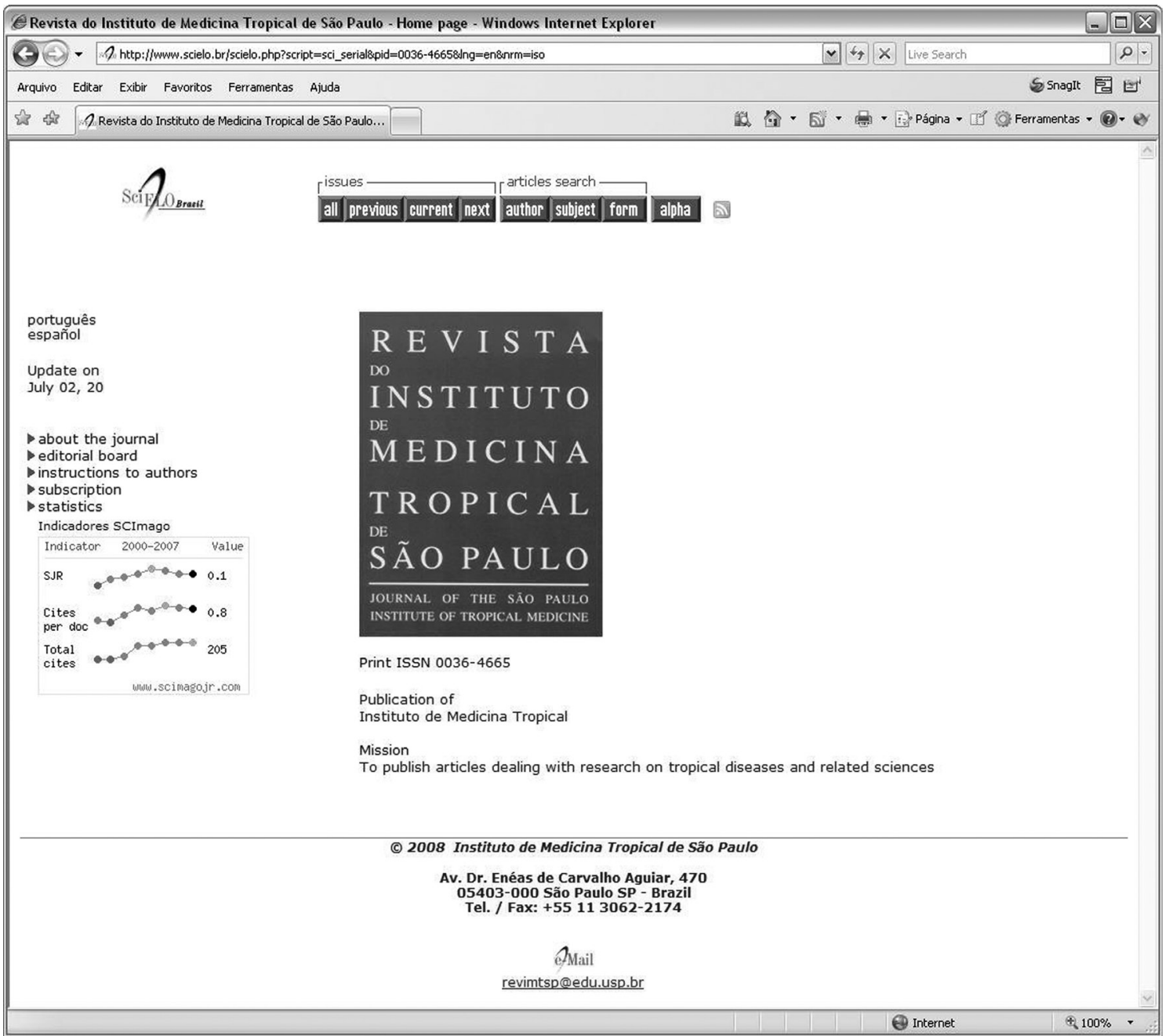

SciELO - The Scientific Electronic Library OnLine - SciELO is an electronic virtual covering a selected collection of Brazilian scientific journals.

The library is an integral part of a project being developed by FAPESP - Fundação de Amparo à Pesquisa do Estado de São Paulo, in partnership with BIREME - the Latin American and Caribbean Center on Health Sciences Information.

SciELO interface provides access to its serials collection via an alphabetic list of titles or a subject index or a search by word of serial titles, publisher names, city of publication and subject.

The interface also provides access to the full text of articles via author index or subject index or a search form on article elements such as author names, words from title, subject and words from full text.

FAPESP/BIREME Project on Scientific Electronic Publications Latin American and Caribbean Center on Health Sciences Information

Rua Botucatu 862 - 04023-901 São Paulo, SP - Brazil

Tel. (011) 5576-9863

scielo@bireme.br 